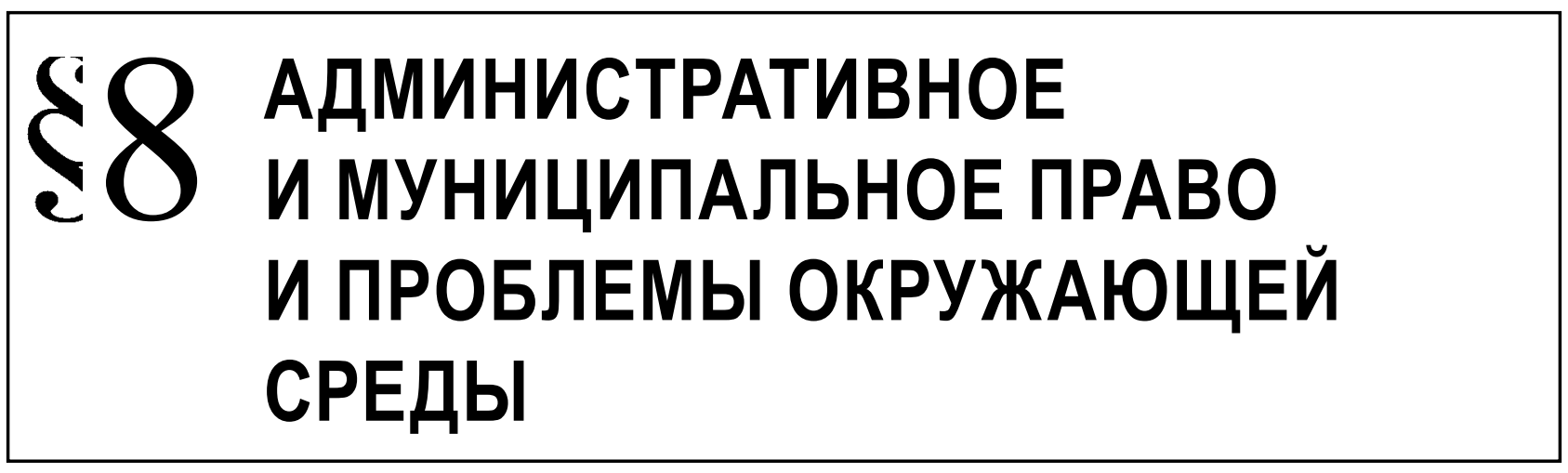

Курилова Е.В.

\title{
СИСТЕМА ОРГАНОВ ВЛАСТИ, ПРИМЕНЯЮЩИХ ЗАКОНОДАТЕЛЬСТВО ОБ АДМИНИСТРАТИВНОЙ ОТВЕТСТВЕННОСТИ В ЭКОЛОГИЧЕСКОЙ СФЕРЕ, ПРИ ОСУЩЕСТВЛЕНИИ ПРОКУРОРСКОГО НАДЗОРА
}

\begin{abstract}
Аннотация: При организации и осуществлении прокурорского надзора за исполнением законодательства об административной ответственности в экологической срере необходимо, прежде всего, представлять весь перечень поднадзорных уполномоченных органов власти и их должностных лиц, осуществляющих административное преследование в рассматриваемом направлении, поскольку указанные органы и должностные лица зачастую сами допускают нарушения требований федерального или регионального законодательства, что, $в$ свою очередь, затрагивает права, свободы и законные интересы граждан, должностных и юридических лиц. Методологическую основу работы составили общенаучный диалектический и частнонаучные методы познания социально-правовых явлений, осуществления и организации прокурорского надзора за исполнением законодательства об административной ответственности в экологической срере. Анализ действующего законодательства показал, что система органов власти, применяющих законодательство об административной ответственности в экологической сфере, при осуществлении прокурорского надзора отличается своей спецификой и обусловлена делением административных правонарушений в экологической срере на правонарушения, устанавливаемые КоАП РФ на федеральном уровне, и правонарушения, закрепляемые законами субъектов Российской Федерации.Полномочия применять указанное законодательство рассредоточиваются по федеральным органам исполнительной власти (федеральным министерствам, службам, агентствам), их территориальным органам и структурным подразделениям, передаются органам исполнительной власти субъектов Российской Федерации и органам местного самоуправления в соответствии с предметами ведения Российской Федерации и ее субъектов. В статье приводится четкое представление о системе органов власти, применяющих законодательство об административной ответственности в экологической сфере, что способствует осуществлению надлежащим образом прокурорского надзора в рассматриваемом направлении.
\end{abstract}

Ключевые слова: прокурорский, надзор, административная, ответственность, экологическая, сфера, прокурор, система, органов, власти.

$\Pi$ ри организации и осуществлении прокурорского надзора за исполнением законодательства об административной ответственности в экологической сфере необходимо, прежде всего, представлять весь перечень поднадзорных уполномоченных органов и их должностных лиц, осуществляющих административное преследова- ние в рассматриваемом направлении, поскольку указанные органы и должностные лица зачастую сами допускают нарушения требований федерального или регионального законодательства, что, в свою очередь, затрагивает права, свободы и законные интересы граждан, должностных и юридических лиц. 
Анализ действующего законодательства показал, что система органов власти, применяющих законодательство об административной ответственности в экологической сфере, при осуществлении прокурорского надзора обусловлена делением административных правонарушений в экологической сфере на правонарушения, устанавливаемые КоАП РФ на федеральном уровне, и правонарушения, закрепляемые законами субъектов Российской Федерации.

Полномочия применять указанное законодательство рассредоточиваются по федеральным органам исполнительной власти (федеральным министерствам, службам, агентствам), их территориальным органам и структурным подразделениям, передаются органам исполнительной власти субъектов Российской Федерации и органам местного самоуправления в соответствии с установленными ст. ст. 1.3 и 1.3.1 КоАП РФ предметами ведения Российской Федерации и ее субъектов.

Статья 22.2 КоАП РФ содержит перечень должностных лиц, наделенных правом рассматривать дела об административных правонарушениях от имени соответствующих федеральных органов исполнительной власти, их структурных подразделений, территориальных органов, к которым относятся: 1) руководители и заместители руководителя соответствующих федеральных органов исполнительной власти; 2) руководители структурных подразделений и территориальных органов соответствующих федеральных органов исполнительной власти, их заместители; 3 ) иные должностные лица, осуществляющие в соответствии с федеральными законами либо нормативными правовыми актами Президента Российской Федерации или Правительства Российской Федерации надзорные или контрольные функции.

Что касается должностных лиц, уполномоченных составлять протоколы об административных правонарушениях, предусмотренных законами субъектов Федерации, то в силу ч. 6 ст. 28.3 КоАП РФ их перечень определяется законами субъекта Российской Федерации. Дела об административных правонарушениях, предусмотренных законами субъектов Федерации, от имени органов, указанных в ст. 22.1 КоАП РФ, рассматривают уполномоченные должностные лица органов исполнительной власти субъектов Федерации.

Перечисленные должностные лица, уполномоченные составлять протокол об административном правонарушении в соответствии со ст. 28.3 КоАП РФ, также вправе принимать решение о возбуждении дела об административном правонарушении и проведении административного расследования в соответствии с ч. 1 ст. 28.7 КоАП РФ, согласно которой административное расследование проводится в случаях, если после выявления административного правонарушения в области охраны окружающей среды осуществляется экспертиза или иные процессуальные действия, требующие значительных временных затрат.

Вторую группу составляют должностные лица органов, применяющие меры обеспечения производства по делам об административных правонарушениях, например, доставление и административное задержание (ст. ст. 27.2 и 27.3 КоАП РФ). Согласно ч. 1 ст. 27.2 КоАП РФ доставление, то есть принудительное препровождение физического лица, а в случаях, предусмотренных пунктами 8 и 10.1 данной части, судна и других орудий совершения административного правонарушения в целях составления протокола об административном правонарушении при невозможности его составления на месте выявления административного правонарушения, если составление протокола является обязательным, осуществляется:

1) должностными лицами органов внутренних дел (полиции) при выявлении административных правонарушений, дела о которых в соответствии со статьей 23.3 КоАП РФ рассматривают органы внутренних дел (полиция), либо административных правонарушений, по делам о которых в соответствии с п. 1 ч. 2 ст. 28.3 КоАП РФ органы внутренних дел (полиция) составляют протоколы об административных правонарушениях в экологической сфере, а также при выявлении любых административных правонарушений в случае обращения к ним должностных лиц, уполномоченных составлять протоколы о соответствующих административных правонарушениях (п. 1 ч. 1 ст. 28.2 КоАП РФ);

2) должностными лицами органов, на которые возложен надзор или контроль за соблюдением законодательства в области охраны окружающей среды, лесного законодательства, законодательства о животном мире, законодательства о рыболовстве и сохранении водных биологических ресурсов, при выявлении административных правонарушений в соответствующей сфере (п.6 ч. 1 ст. 28.2 КоАП РФ);

3) должностными лицами пограничных органов при выявлении административных правонарушений во внутренних морских водах, в территориальном море, на континентальном шельфе, в 
исключительной экономической зоне Российской Федерации (п. 8 ч. 1 ст. 28.2 КоАП РФ).

При этом пункт 6 ч. 1 ст. 27.2 КоАП РФ предусматривает доставление физического лица в целях составления протокола об административном правонарушении при невозможности его составления на месте выявления проступка, если составление протокола является обязательным. Более того, данное полномочие в полной мере может реализовываться и органами регионального подчинения, отнесенными к перечисленной группе в п. 6 ч. 1 ст. 27.2 КоАП РФ. В то же время такая серьезная мера обеспечения производства по делу как административное задержание (ст. 27.3 КоАП РФ) может применяться специально уполномоченными органами в области охраны окружающей среды и природопользования как федерального, так и регионального подчинения опосредованно - путем обращения в органы внутренних дел.

В соответствии с ч. 1 ст. 27.3 КоАП РФ административное задержание, как кратковременное ограничение свободы физического лица, может быть применено в исключительных случаях, если это необходимо для обеспечения правильного и своевременного рассмотрения дела об административном правонарушении, исполнения постановления по такому делу.

Третью группу составляют органы и должностные лица, перечисленные в Главе 23 КоАП РФ, уполномоченные рассматривать дела об административных правонарушениях, применять законодательство об административной ответственности в экологической сфере.

Федеральные министерства, службы и агентства осуществляют свои полномочия как непосредственно, так и через свои территориальные органы, структурные подразделения, уполномоченных должностных лиц, деятельность и правовые акты которых входят в сферу прокурорского надзора.

Федеральные органы исполнительной власти специальной компетенции в соответствии Указом Президента Российской Федерации от 21.05.2012 №636 «0 структуре федеральных органов исполнительной власти» и Положениям о них осуществляют административно-юрисдикционные полномочия в экологической сфере по следующим статьям КоАП РФ:

1. Федеральная служба по надзору в сфере природопользования (Росприроднадзор ${ }^{1}$ ) со-

1 Об утверждении Положения о Федеральной службе по надзору в сфере природопользования и внесении изменений в постановление Правительства Российской Федерации от гласно ст.ст. 23.21, 23.22, 23.23, 23.24, 23.25, 23.26, 23.29 КоАП РФ в соответствующей части рассматривает дела об административных правонарушениях, предусмотренных статьями 7.1, 7.3, 7.4, 7.6, 7.8 - 7.10, ч. 1 ст. 7.11, 7.34, 7.9, 7.10, 8.1, 8.2, 8.4 - 8.9, ч. 1 ст. $8.10,8.11,8.12-8.15$, ч. 1 ст. 8.13 , ч. 1 ст. 8.16 , ст. $8.17,8.18,8.19,8.20,8.21-8.36$, частями 1 и 1.1 статьи 8.37, ч. 3 статьи 8.37 , ч. 1 ст. $8.28,8.29-8.32$, 8.33 - 8.36, частями $1,1.1,2$ и 3 статьи 8.37, 8.38, 8.39, 8.41, 8.42, 8.44, 8.45 КоАП РФ.

2. Федеральная служба по гидрометеорологии и мониторингу окружающей среды (Росгидромет ${ }^{2}$ ) согласно ст. 23.28 КоАП РФ рассматривает дела об административных правонарушениях, предусмотренных статьей 8.5, частями 1 и 2 статьи 8.40, статьей 8.43 КоАП РФ.

3. Федеральное агентство лесного хозяйства (Рослесхоз) $^{3}$ в силу ст. 23.24 КоАП РФ рассматривает дела об административных правонарушениях, ст. ст. 7.9, 7.10, 8.24 - 8.27, ч.1 ст. 8.28, 8.29 - 8.32 КоАП РФ.

4. Федеральная служба по ветеринарному и фитосанитарному надзору (Россельхознадзор) ${ }^{4}$ согласно ст. ст. 23.15, 23.20 КоАП РФ рассматривает дела об административных правонарушениях, предусмотренных ст. ст. 8.3, 8.6, 8.7 КоАП РФ.

5. Федеральное агентство по рыболовству (Росрыболовство) $^{5}$ в соответствии со ст. 23.27

22.07.2004 № 370: постановление Правительства Российской Федерации от 30.07.2004 № 400 // СЗ РФ. 2004. № 32. Ст. 3347 (с послед. изменениями).

2 О Федеральной службе по гидрометеорологии и мониторингу окружающей среды: постановление Правительства Российской Федерации от 23.07.2004 № 372 // СЗ РФ. 2004. №31. Ст. 3262; приказ Минприроды России от 29.06.2012 № 181 «Об утверждении Административного регламента исполнения Федеральной службой по гидрометеорологии и мониторингу окружающей среды государственной функции по осуществлению государственного надзора за проведением работ по активному воздействию на метеорологические и другие геофизические процессы на территории Российской Федерации» // Бюллетень нормативных актов федеральных органов исполнительной власти. 2013. №2.

О Федеральном агентстве лесного хозяйства: постановление Правительства Российской Федерации от 23.09.2010 № 736 // СЗ РФ. 04.10.2010. № 40. Ст. 5068. (с последующим изменениями).

4 Об утверждении Положения о Федеральной службе по ветеринарному и фитосанитарному надзору: постановление Правительства Российской Федерации от 30.06.2004 № 327 // Российская газета. 15.07.2004. №150 (с послед. изменениями).

5 О Федеральном агентстве по рыболовству: постановление Правительства Российской Федерации от 11.06.2008 № 444 // СЗ РФ. 2008. № 25. Ст. 2979 (с послед. изменениями). 
КоАП РФ рассматривает дела об административных правонарушениях, предусмотренных ч. 1 ст.7.11, ст. ст. 8.33, 8.34, 8.36, частями 2 и 3 ст. 8.37, 8.38, 8.42 КоАП РФ.

6. Федеральная служба государственной регистрации, кадастра и картографии (Росреестр) ${ }^{6}$ согласно ст. 23.21 КоАП РФ рассматривают дела об административных правонарушениях, предусмотренных ст.ст. 7.1, 7.10, 7.34, 8.8 КоАП РФ.

7. Федеральная служба по надзору в сфере защиты прав потребителей и благополучия человека (Роспотребнадзор) ${ }^{7}$ в силу ст. 23.13 КоАП РФ рассматривает дела об административных правонарушениях, предусмотренных ст.ст. 8.2, 8.5, ч. 2 ст. 8.42 КоАП РФ.

8. Федеральная служба по экологическому, технологическому и атомному надзору (Ростехнадзор) $^{8}$ в соответствии со ст. ст. 23.29, 23.31, 23.33 КоАП РФ рассматривает дела об административных правонарушениях, предусмотренных ст.ст. ч. 2 ст. 7.3, 7.4, 7.6, ч. 1 ст.7.11, 8.1, 8.2, 8.4 - 8.7, ч. 2 ст. $8.10,8.12$, частями $1,2,4$ ст. 8.13 , частью 1 ст. $8.14,8.15$, частями 1 и 3 статьи 8.17, 8.18, 8.19, $8.21-8.23$, частями 2 и 3 ст. $8.31,8.33-8.36$, ч. 3 ст.8.37, 8.39, 8.41 КоАП РФ.

9. Министерство Российской Федерации по делам гражданской обороны, чрезвычайным ситуациям и ликвидации последствий стихийных бедствий (МЧС России) ${ }^{9}$ в силу ст.ст. 23.34, 23.40 КоАП РФ рассматривает дела об

\footnotetext{
6 О Федеральной службе государственной регистрации, кадастра и картографии: постановление Правительства Российской Федерации от 01.06.2009 № 457 // СЗ РФ. 2009. № 25. Ст. 3052 (с послед. изменениями).

Об утверждении Положения о Федеральной службе по надзору в сфере защиты прав потребителей и благополучия человека: постановление Правительства Российской Федерации от 30.06.2004 № 322// СЗ РФ. 2004. № 28. Ст. 2899 (с послед. изменениями).

8 О Федеральной службе по экологическому, технологическому и атомному надзору: постановление Правительства Российской Федерации от 30.07.2004 № 401 // СЗ РФ. 2004. № 32. Ст. 3348. (с послед. изменениями).

9 Вопросы Министерства Российской Федерации по делам гражданской обороны, чрезвычайным ситуациям и ликвидации последствий стихийных бедствий: указ Президента Российской Федерации от 11.07.2004 № 868 // СЗ РФ. 2004. №28. Ст. 2882 (с послед. изменениями); О федеральной противопожарной службе Государственной противопожарной службы: постановление Правительства Российской Федерации от 20.06. 2005 № 385// СЗ РФ. 2005. № 26. Ст. 2649 (с послед. изменениями).
}

административных правонарушениях, предусмотренные ст. 8.22, 8.23, 8.32 КоАП РФ.

10. Министерство внутренних дел Российской Федерации (МВД России) (полиция) ${ }^{10}$ согласно ст. 23.3 КоАП РФ рассматривает дела об административных правонарушениях, предусмотренных ст. 8.22, 8.23 КоАП РФ.

11. Министерство обороны Российской Федерации (Минобороны России) (военная автомобильная инспекция) ${ }^{11}$ в силу ст. ст. $23.42,23.77$ КоАП РФ рассматривает дела об административных правонарушениях, предусмотренных ст.ст. 8.2 , 8.3, 8.22, 8.23 КоАП РФ.

12. Федеральная служба безопасности (пограничные органы) ${ }^{12}$ в соответствии со ст. 23.10 КоАП РФ рассматривает дела об административных правонарушениях, предусмотренных частью 1 статьи 7.11 , ст.ст. $8.16-8.20,8.33,8.35$, ч. 2 ст. 8.37 , 8.38 КоАП РФ.

13. Федеральная служба по надзору в сфере транспорта (Ространснадзор) ${ }^{13}$ согласно ст.ст. 23.35, 23.36, 23.42 КоАП РФ рассматривает дела об административных правонарушениях, предусмотренных ст.ст. 8.2, 8.3, 8.22, 8.23 КоАП РФ.

Четкое представление о системе органов власти, применяющих законодательство об административной ответственности в экологической сфере, способствует осуществлению надлежащим образом прокурорского надзора в рассматриваемом направлении. 
Библиография:

1. Об утверждении Положения о Федеральной службе по надзору в сфере природопользования и внесении изменений в постановление Правительства Российской Федерации от 22.07.2004 № 370: постановление Правительства Российской Федерации от 30.07.2004 № 400 // СЗ РФ. 2004. № 32. Ст. 3347 (с послед. изменениями).

2. О Федеральной службе по гидрометеорологии и мониторингу окружающей среды: постановление Правительства Российской Федерации от 23.07.2004 № 372 // СЗ РФ. 2004. №31. Ст. 3262; приказ Минприроды России от 29.06.2012 № 181 «Об утверждении Административного регламента исполнения Федеральной службой по гидрометеорологии и мониторингу окружающей среды государственной функции по осуществлению государственного надзора за проведением работ по активному воздействию на метеорологические и другие геофизические процессы на территории Российской Федерации» // Бюллетень нормативных актов федеральных органов исполнительной власти. 2013. №2.

3. О Федеральном агентстве лесного хозяйства: постановление Правительства Российской Федерации от 23.09 .2010 № 736 // СЗ РФ. 04.10.2010. № 40. Ст. 5068. (с последующим изменениями).

4. Об утверждении Положения о Федеральной службе по ветеринарному и фитосанитарному надзору: постановление Правительства Российской Федерации от 30.06.2004 № 327 // Российская газета. 15.07.2004. №150 (с послед. изменениями).

5. О Федеральном агентстве по рыболовству: постановление Правительства Российской Федерации от 11.06 .2008 № 444 // СЗ РФ. 2008. № 25. Ст. 2979 (с послед. изменениями).

6. О Федеральной службе государственной регистрации, кадастра и картографии: постановление Правительства Российской Федерации от 01.06.2009 № 457 // СЗ РФ. 2009. № 25. Ст. 3052 (с послед. изменениями).

7. Об утверждении Положения о Федеральной службе по надзору в сфере защиты прав потребителей и благополучия человека: постановление Правительства Российской Федерации от 30.06.2004 № 322// СЗ РФ. 2004 . № 28. Ст. 2899 (с послед. изменениями).

8. О Федеральной службе по экологическому, технологическому и атомному надзору: постановление Правительства Российской Федерации от 30.07.2004 № 401 // СЗ РФ. 2004. № 32. Ст. 3348. (с послед. изменениями).

9. Вопросы Министерства Российской Федерации по делам гражданской обороны, чрезвычайным ситуациям и ликвидации последствий стихийных бедствий: указ Президента Российской Федерации от 11.07.2004 № 868 // СЗ РФ. 2004. №28. Ст. 2882 (с послед. изменениями); О федеральной противопожарной службе Государственной противопожарной службы: постановление Правительства Российской Федерации от 20.06. 2005 № $385 / /$ СЗ РФ. 2005. № 26. Ст. 2649 (с послед. изменениями).

10. Вопросы Министерства внутренних дел Российской Федерации: указ Президента Российской Федерации от 01.03.2011 № 248// СЗ РФ. 2011. № 10. Ст. 1334 (с послед. изменениями); Федеральный закон от 07.02 .2011 № 3-ФЗ «О полиции» // СЗ РФ. 2011. №7. Ст. 900 (с послед. изменениями).

11. Вопросы Министерства обороны Российской Федерации: указ Президента Российской Федерации от 16.08 .2004 № 1082 // СЗ РФ. 2004. № 34. Ст. 3538 (с послед. изменениями); Об утверждении общевоинских уставов Вооруженных Сил Российской Федерации: указ Президента Российской Федерации от 10.11.2007 № 1495// С3 РФ. 2007. № 47 (1 ч.). Ст. 5749 (с послед. изменениями).

12. См. Федеральный закон от 03.04.1995 № 40-ФЗ «О Федеральной службе безопасности» // СЗ РФ. 1995. №15. Ст. 1269 (с послед. изменениями).

13. Об утверждении Положения о Федеральной службе по надзору в сфере транспорта: постановление Правительства Российской Федерации от 30.07.2004 № 398 // СЗ РФ. 2004. №32. Ст. 3345 (с послед. изменениями).

\section{References (transliterated):}

1. Ob utverzhdenii Polozheniya o Federal'noi sluzhbe po nadzoru v sfere prirodopol'zovaniya i vnesenii izmenenii v postanovlenie Pravitel'stva Rossiiskoi Federatsii ot 22.07.2004 № 370: postanovlenie Pravitel'stva Rossiiskoi Federatsii ot 30.07.2004 № 400 // SZ RF. 2004. № 32. St. 3347 (s posled. izmeneniyami).

2. O Federal'noi sluzhbe po gidrometeorologii i monitoringu okruzhayushchei sredy: postanovlenie Pravitel'stva Rossiiskoi Federatsii ot 23.07.2004 № 372 // SZ RF. 2004. №31. St. 3262; prikaz Minprirody Rossii ot 29.06.2012 № 181 «0b utverzhdenii Administrativnogo reglamenta ispolneniya Federal'noi sluzhboi po gidrometeorologii i monitoringu okruzhayushchei sredy gosudarstvennoi funktsii po osushchestvleniyu gosudarstvennogo nadzora za provedeniem rabot po aktivnomu vozdeistviyu na meteorologicheskie i drugie geofizicheskie protsessy na territorii Rossiiskoi Federatsii» // Byulleten' normativnykh aktov federal'nykh organov ispolnitel'noi vlasti. 2013. №2.

3. O Federal'nom agentstve lesnogo khozyaistva: postanovlenie Pravitel'stva Rossiiskoi Federatsii ot 23.09 .2010 № 736 // SZ RF. 04.10.2010. № 40. St. 5068. (s posleduyushchim izmeneniyami).

4. Ob utverzhdenii Polozheniya o Federal'noi sluzhbe po veterinarnomu i fitosanitarnomu nadzoru: postanovlenie Pravitel'stva Rossiiskoi Federatsii ot 30.06.2004 № 327 // Rossiiskaya gazeta.15.07.2004. №150 (s posled. izmeneniyami).

5. O Federal'nom agentstve po rybolovstvu: postanovlenie Pravitel'stva Rossiiskoi Federatsii ot 11.06.2008 № 444 // SZ RF. 2008. № 25. St. 2979 (s posled. izmeneniyami). 


\section{Административное и муниципальное право $10(82) \cdot 2014$}

6. O Federal'noi sluzhbe gosudarstvennoi registratsii, kadastra i kartografii: postanovlenie Pravitel'stva Rossiiskoi Federatsii ot 01.06.2009 № 457 // SZ RF. 2009. № 25. St. 3052 (s posled. izmeneniyami).

7. Ob utverzhdenii Polozheniya o Federal'noi sluzhbe po nadzoru v sfere zashchity prav potrebitelei i blagopoluchiya cheloveka: postanovlenie Pravitel'stva Rossiiskoi Federatsii ot 30.06.2004 № 322// SZ RF. 2004. № 28. St. 2899 (s posled. izmeneniyami).

8. O Federal'noi sluzhbe po ekologicheskomu, tekhnologicheskomu i atomnomu nadzoru: postanovlenie Pravitel'stva Rossiiskoi Federatsii ot 30.07.2004 № 401 // SZ RF. 2004. № 32. St. 3348. (s posled. izmeneniyami).

9. Voprosy Ministerstva Rossiiskoi Federatsii po delam grazhdanskoi oborony, chrezvychainym situatsiyam i likvidatsii posledstvii stikhiinykh bedstvii: ukaz Prezidenta Rossiiskoi Federatsii ot 11.07.2004 № 868 // SZ RF. 2004 . №28. St. 2882 (s posled. izmeneniyami); 0 federal'noi protivopozharnoi sluzhbe Gosudarstvennoi protivopozharnoi sluzhby: postanovlenie Pravitel'stva Rossiiskoi Federatsii ot 20.06. 2005 № 385// SZ RF. 2005. № 26. St. 2649 (s posled. izmeneniyami).

10. Voprosy Ministerstva vnutrennikh del Rossiiskoi Federatsii: ukaz Prezidenta Rossiiskoi Federatsii ot 01.03.2011 № 248// SZ RF. 2011. № 10. St. 1334 (s posled. izmeneniyami); Federal'nyi zakon ot 07.02.2011 № 3-FZ «0 politsii» // SZ RF. 2011. №7. St. 900 (s posled. izmeneniyami).

11. Voprosy Ministerstva oborony Rossiiskoi Federatsii: ukaz Prezidenta Rossiiskoi Federatsii ot 16.08 .2004 № 1082 // SZ RF. 2004. № 34. St. 3538 (s posled. izmeneniyami); Ob utverzhdenii obshchevoinskikh ustavov Vooruzhennykh Sil Rossiiskoi Federatsii: ukaz Prezidenta Rossiiskoi Federatsii ot 10.11.2007 № 1495// SZ RF. 2007. № 47 (1 ch.). St. 5749 (s posled. izmeneniyami).

12. Sm. Federal'nyi zakon ot 03.04.1995 № 40-FZ «O Federal'noi sluzhbe bezopasnosti» // SZ RF. 1995. №15. St. 1269 (s posled. izmeneniyami).

13. Ob utverzhdenii Polozheniya o Federal'noi sluzhbe po nadzoru v sfere transporta: postanovlenie Pravitel'stva Rossiiskoi Federatsii ot 30.07.2004 № 398 // SZ RF. 2004. №32. St. 3345 (s posled. izmeneniyami). 